\title{
Zika virus infections in three travellers returning from South America and the Caribbean respectively, to Montpellier, France, December 2015 to January 2016
}

\author{
AT Maria ${ }^{12}$, M Maquart $^{3}$, A Makinson ${ }^{12}$, 0 Flusin ${ }^{3}$, M Segondy ${ }^{245}$, I Leparc-Goffart ${ }^{3}$, V Le Moing ${ }^{12}$, V Foulongne ${ }^{245}$ \\ 1. Department of Infectious Diseases and Tropical Medicine, Montpellier University Hospital, Montpellier, France \\ 2. University of Montpellier, Montpellier, France \\ 3. Centre national de référence des Arbovirus, Institut de Recherche Biomédicale des Armées, Marseille, France \\ 4. Laboratory of Virology, Montpellier University Hospital, Montpellier, France \\ 5. INSERM U1058, Pathogenesis and Control of Chronic Infections, Montpellier, France
}

Correspondence: Vincent Foulongne (v-foulongne@chu-montpellier.fr)

Citation style for this article:

Maria A, Maquart M, Makinson A, Flusin O, Segondy M, Leparc-Goffart I, Le Moing V, Foulongne V. Zika virus infections in three travellers returning from South America and the Caribbean respectively, to Montpellier, France, December 2015 to January 2016. Euro Surveill. 2016;21(6):pii=30131. DOI: http://dx.doi. org/10.2807/1560-7917.ES.2016.21.6.30131

Article submitted on 28 January 2015 / accepted on 10 February 2016 / published on 11 February 2016

We report three unrelated cases of Zika virus infection in patients returning from Martinique, Brazil and Colombia respectively, to Montpellier, France. They developed symptoms compatible with a mosquito-borne disease, and serological and molecular investigations indicated a recent Zika virus infection. Considering the recent warning for the likely teratogenicity of Zika virus and the presence of competent mosquito vectors in southern France, these cases highlight the need for awareness of physicians and laboratories in Europe.

Since early 2015 there has been a rapid spread of Zika virus infections in South America with a subsequent threat for importation of that emerging disease in other regions of the world. Here we describe three cases in travellers returning to France from affected areas.

\section{Description of cases}

Case 1

On 24 December 2015, a woman in her sixties presented at the Department of Infectious and Tropical Diseases at the University Hospital of Montpellier, France. Three days earlier she had developed sudden fever associated with myalgia, maculopapular rash located on face, trunk and limbs, and conjunctivitis. Symptoms onset occurred two days after having returned from a three-week vacation on Martinique Island (French West Indies). Blood cell count, liver enzymes and renal function were normal. Fever and rash resolved on day 3, but fatigue and muscular symptoms lasted for seven days. Zika virus (ZIKV) real-time polymerase chain reaction (RT-PCR) was negative in blood on day 5 after symptom onset; urine samples were not collected for testing. ZIKV IgM antibodies were detected on 24 December (day 5 after symptom onset) with an increasing level in subsequent samples, whereas the rise of ZIKV IgG antibodies was noticed three weeks later.

\section{Case 2}

On 13 January 2016, a man in his twenties was examined in the same department. He had experienced gradual onset of fever, myalgia, diarrhoea, arthralgia and cutaneous rash on trunk and limbs, starting on 5 January, one day after his return from a one-week stay in Rio de Janeiro, Brazil. Upon examination in hospital, fever and cutaneous rash had disappeared, but arthralgia persisted, in association with asthenia, non-productive cough and conjunctivitis. On the day of admission (13 January), laboratory tests showed normal blood cell count and normal renal function, while transaminases were slightly increased. RT-PCR for ZIKV was negative in blood and urine samples. ZIKV IgG and IgM antibodies were detected in serum concomitantly with DENV antibodies; however, the specificity of these anti-ZIKV antibodies was confirmed by a neutralisation assay. Three of the patient's relatives living in Brazil were concurrently diagnosed with symptomatic ZIKV infection.

\section{Case 3}

A man in his fifties progressively developed myalgia in lower limbs, pruriginous rash and fever, two days after returning from a three-week vacation in Columbia. He was examined in the same hospital department on the third day (13 January), and showed intense fatigue, extensive maculopapular eruption on the face, trunk and both upper and lower limbs, ulcerative pharyngitis, and conjunctivitis. Results of the neurological examination were normal. Blood cell count showed mild leucopenia (3,800 cells/ $\mu \mathrm{L}$; norm: >4,000 cells $/ \mu \mathrm{L})$, 
Temporal and virological data related to three imported cases of Zika virus infection, Montpellier, France, December 2015 to January 2016

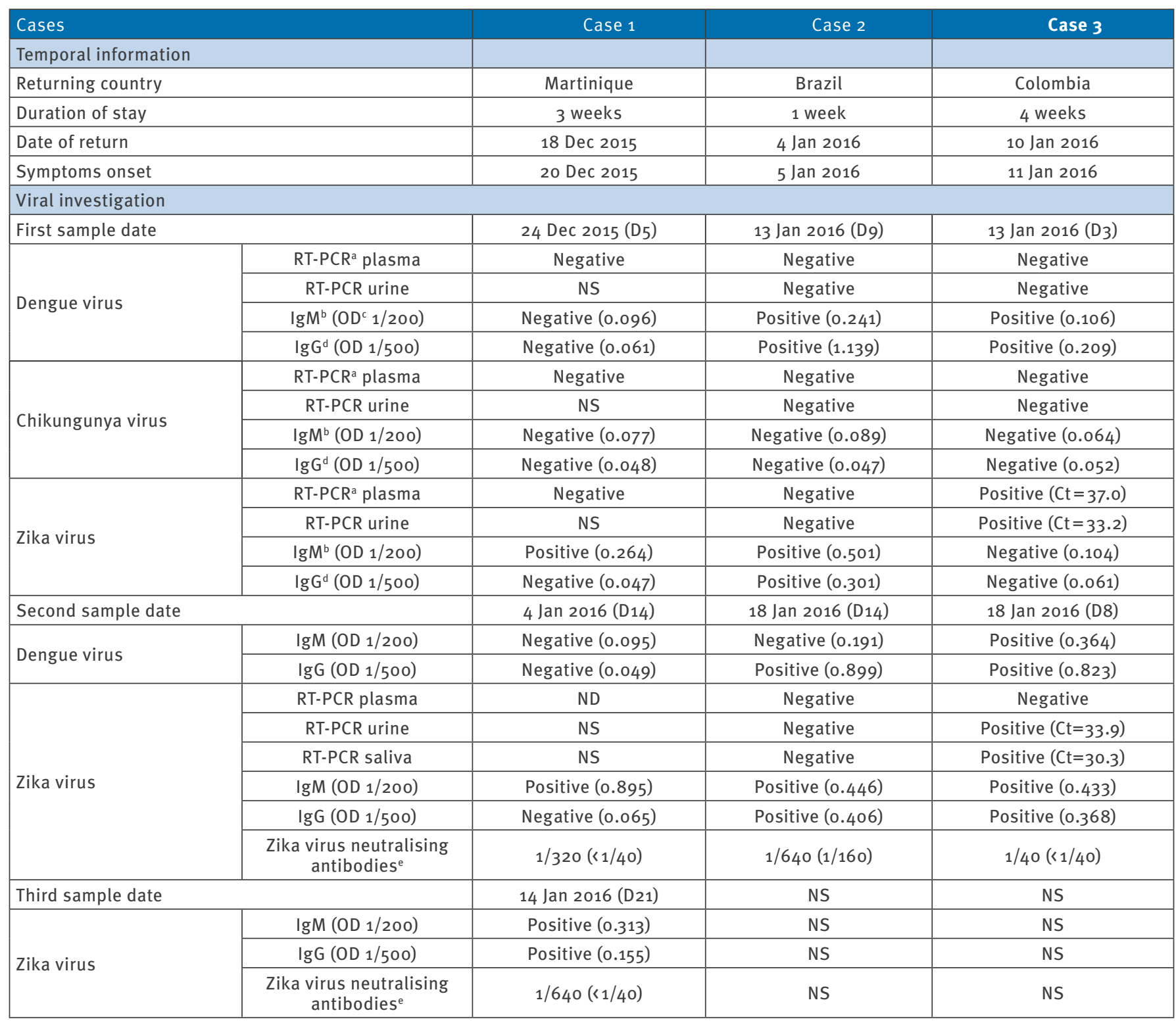

Ct: Cycles threshold; D: days from symptom onset; ND: not determined; NS: not sampled; OD: optical density; RT-PCR: real-time polymerase chain reaction.

a RT-PCRs were performed with the RealStar dengue RT-PCR kit 2.0, the RealStar chikungunya RT-PCR kit 1.0 and the RealStar Zika virus RTPCR kit 1.0 (Altona Diagnostic, Germany).

${ }^{b}$ Flaviriruses IgM and chikungunya virus IgM detections were performed with in house IgM antibody-capture ELISA (MAC-ELISA) asSays.

${ }^{c}$ At $1 / 200$ or $1 / 500$ working dilutions.

d Flaviriruses IgG and chikungunya virus IgG detections were performed with in house indirect ELISA assays.

e Zika virus neutralising antibodies (result of West Nile virus neutralisation antibodies assay performed as control) with the titre of serum neutralising $90 \%$.

with normal liver enzymes and renal function. RT-PCR for ZIKV was positive in blood, urine and saliva samples. ZIKV seroconversion was detected in the second sample (day 8 after symptom onset) with observation of cross-reactivity with flaviviruses including dengue. Interestingly, two relatives who travelled with him were subsequently tested, and the results were negative for ZIKV.
Symptoms disappeared completely within one week in all patients. Temporal and viral investigation data are summarised in the Table.

\section{Background}

Zika virus is a mosquito-borne flavivirus related to dengue virus (DENV), yellow fever virus (YFV) and West Nile virus (WNV). A large outbreak of ZIKV infections involving the ZIKV Asian lineage is ongoing in Brazil since April 2015 [1] with up to 18 countries affected as 
at 23 December 2015 [2]. By the first week of December 2015, nine additional South American countries and Cape Verde islands had reported locally acquired cases [3]. Furthermore, a link between ZIKV infection and neurological disorders or congenital malformations has been suspected in Brazil, and an epidemiological alert from the Pan American Health Organization (PAHO) has been issued [4]. ZIKV which is transmitted by Aedes aegypti has been isolated from several Aedes mosquito species [5] and transmission by $A e$. albopictus has been documented in Gabon [6], leading to the threat of a worldwide spread. In the last week of December, the French Ministry of Health issued a warning about the detection of autochthonous cases of ZIKV infections in French Departments of America, French Guyana and Martinique Island, confirming the spread of ZIKV in the Caribbean [7]. Given that South American and Caribbean countries are highly touristic regions and that European overseas districts in that area have close connections with their related European mainland countries, there is a risk for imported cases to occur in Europe.

\section{Discussion and conclusions}

No autochthonous case of ZIKV infection and a limited number of cases related to the South American outbreak have been reported so far in Europe. The first one was observed in Italy, at the beginning of the Brazilian outbreak, in a traveller returning from Brazil [8] and, more recently, in November 2015, in a traveller returning to the Netherlands from Surinam [3]. Interestingly, similarly to Case 1 returning from Martinique, these imported cases were concomitantly detected close to the first reported locally-acquired cases. Since most ZIKV infections are asymptomatic or mild, this suggests that, at the time of the first autochthonous cases, the overall burden of ZIKV infection has been underestimated.

Since its first introduction in 2004 , the mosquito vector Ae. albopictus has been well established in southern France. Autochthonous transmissions of chikungunya virus (CHIKV) or DENV previously occurred in Europe $[9,10]$, such as in Montpellier, with an outbreak of 12 locally acquired CHIKV infections in October 2014 [11] or in Nimes, a nearby town, with an outbreak of six autochthonous DENV infection cases in 2015 [12]. Thus, prerequisites for ZIKV autochthonous transmission are likely met in southern France. However, despite the fact that Ae. albopictus is an in vitro competent vector for the ZIKV African lineage [13] and was identified as an efficient vector for this lineage in Gabon [6], its vectorial capacity for the ZIKV Asian lineage remains to be clarified. Furthermore, in the cases reported here, the risk of local transmission can be ruled out, considering the vector inactivity during winter time.

However, this description of imported cases, including one case from a French Overseas Department, should reinforce the preparedness plan for arboviral outbreaks which is implemented each year since
2006, during the Ae. albopictus activity period (May to November), in all Ae. albopictus-colonised areas in France [11]. This means that the network of laboratories that currently propose CHIKV and DENV diagnosis should add ZIKV diagnosis to their panel, with regular reports to regional surveillance boards, and that practitioners' awareness of clinically-suspected cases must be raised; moreover, they should be required to report to regional health authorities. However, as illustrated here, the laboratory diagnosis of ZIKV infection might be challenging due to the transient viraemia, the antibody rise that might be delayed, and the IgG flavivirus cross-reactivity that may interfere in serological testing. This will be a concern for the surveillance of pregnant women [14] as well as for blood safety policy [15].

\section{Conflict of interest}

None declared.

\section{Authors' contributions}

Managed the patients: ATM, AM, VLM; performed laboratory investigations: MM, OF, ILG, VF; wrote the manuscript: ATM, MS, VLM, VF.

\section{References}

1. Campos GS, Bandeira AC, Sardi SI. Zika virus outbreak, Bahia, Brazil.Emerg Infect Dis. 2015;21(10):1885-6. DOI: 10.3201/ eid2110.150847 PMID: 26401719

2. Ministério Da Saûde (Brazil). Monitoramento dos casos de dengue, febre de chikungunya et febre pelo virus zika até a seman Epidémiologica 48, 2015. [Monitoring cases of dengue, chikungunya, zika virus infections as of epidemiological week 48]. Brasília: Ministério Da Saûde. [Accessed 23 December 2015]. Portuguese. Available from: http://portalsaude.saude. gov.br/images/pdf/2015/dezembro/23/2015-049---Dengue-SE48---para-publica----0-21.12.15.pdf

3. European Center for Disease Prevention and Control (ECDC). Communicable disease threats report, week 51, 13-19 December 2015. Stockholm: ECDC. 2015. Available from: http:// ecdc.europa.eu/en/publications/Publications/Communicabledisease-threats-report-19-dec-2015.pdf

4. Pan American Health Organization (PAHO). Epidemiological Alert. Neurological syndrome, congenital malformations, and. Zika virus infection. Implications for public health in the Americas Organization. Washington: PAHO. [Accessed 1 Dec 2015]. Available from: http://www.paho.org/hq/index. php?option $=$ com_content\&view $=$ category \&layout=blog\&id $=12$ 18\&ltemid $=2291$ \&lang $=\mathrm{fr}$

5. Diallo D, Sall AA, Diagne CT, Faye O, Faye O, Ba Y, et al. Zika virus emergence in mosquitoes in southeastern Senegal, 2011. PLoS One. 2014;9(10):e109442. DOI: 10.1371/journal. pone.0109442 PMID: 25310102

6. Grard G, Caron M, Mombo IM, Nkoghe D, Mboui Ondo S, Jiolle D, et al. Zika virus in Gabon (Central Africa)--2007: a new threat from Aedes albopictus? PLoS Negl Trop Dis 2014;8(2):e2681. DOI: 10.1371/journal.pntd.0002681 PMID: 24516683

7. European Center for Disease Prevention and Control (ECDC). Communicable disease threats report, week 52, 20-26 December 2015. Stockholm: ECDC. Available from: http:// ecdc.europa.eu/en/publications/Publications/Communicabledisease-threats-report-26-dec-2015.pdf.

8. Zammarchi L, Tappe D, Fortuna C, Remoli ME, Günther $\mathrm{S}$, Venturi G, et al. Zika virus infection in a traveller returning to Europe from Brazil, March 2015. Euro Surveill. 2015;20(23):21153. DOI: $10.2807 / 1560-7917 . E S 2015 \cdot 20.23 \cdot 21153$ PMID: 26084316

9. Grandadam M, Caro V, Plumet S, Thiberge JM, Souarès $Y$, Failloux $A B$, et al. Chikungunya virus, southeastern France. Emerg Infect Dis. 2011;17(5):910-3. DOI: 10.3201/ eid1705.101873 PMID: 21529410 
10. Marchand E, Prat C, Jeannin C, Lafont E, Bergmann T, Flusin O, et al. Autochthonous case of dengue in France, October 2013 Euro Surveill. 2013;18(50):20661. DOI: 10.2807/1560-7917 ES2013.18.50.20661 PMID: 24342514

11. Delisle E, Rousseau C, Broche B, Leparc-Goffart I, L'Ambert G, Cochet $A$, et al. Chikungunya outbreak in Montpellier, France, September to October 2014. Euro Surveill. 2015;20(17):21108. DOI: $10.2807 / 1560-7917 . E S 2015 \cdot 20.17 .21108$ PMID: 25955774

12. Institut National de Veille Sanitaire (INVS). Surveillance sanitaire en Languedoc-Roussillon. Point épidémiologique au 4 Novembre 2015. [Medical surveillance in Languedoc-Roussillon. Epidemiological point 4 Nov 2015]. Paris: INVS. [Accessed 11 November 2015]. French. Available from: http://www.invs. sante.fr/fr/Publications-et-outils/Points-epidemiologiques/ Tous-les-numeros/Languedoc-Roussillon/2015/Surveillancesanitaire-en-Languedoc-Roussillon.-Point-epidemiologique-au4-novembre-2015

13. Wong PS, Li MZ, Chong CS, Ng LC, Tan CH. Aedes (Stegomyia) albopictus (Skuse): a potential vector of Zika virus in Singapore.PLoS Negl Trop Dis. 2013;7(8):e2348. DOI: 10.1371/ journal.pntd.0002348 PMID: 23936579

14. Petersen EE, Staples JE, Meaney-Delman D, Fischer M, Ellington SR, Callaghan WM, et al. Interim guidelines for pregnant women during a Zika virus outbreak- United States, 2016. MMWR Morb Mortal Wkly Rep. 2016;65(2):30-3. DOI: 10.15585/mmwr.mm6502e1 PMID: 26796813

15. Marano G, Pupella S, Vaglio S, Liumbruno GM, Grazzini G. Zika virus and the never-ending story of emerging pathogens and transfusion medicine.Blood Transfus. 2015;5:1-6.PMID: 26674815

\section{License and copyright}

This is an open-access article distributed under the terms of the Creative Commons Attribution (CC BY 4.0) Licence. You may share and adapt the material, but must give appropriate credit to the source, provide a link to the licence, and indicate if changes were made.

This article is copyright of the authors, 2016. 